\title{
KEBIJAKAN PEMERINTAH DAN ADAPTASI MASYARAKAT DALAM PENANGGULANGAN DAMPAK BANJIR TERHADAP USAHA BUDIDAYA IKAN DI TAMBAK
}

\section{Goverment Policy and Society Adaptation in Order to Overcome Flood Impact of Bussiness on Fish Farming in Pond}

\author{
"Nendah Kurniasari dan Fatriyandi Nur Priyatna \\ Balai Besar Penelitian Sosial Ekonomi Kelautan dan Perikanan \\ Gedung Balitbang KP I Lt. 4 \\ Jalan Pasir Putih Nomor 1 Ancol Timur, Jakarta Utara \\ Telp: (021) 64711583 Fax: 64700924 \\ "email: nendahkurniasari@gmail.com
}

Diterima 23 September 2014 - Disetujui 29 Nopember 2014

\begin{abstract}
ABSTRAK
Penelitian bertujuan memberikan gambaran mengenai strategi mitigasi yang dilakukan oleh pemerintah serta strategi adaptasi masyarakat dalam menghadapi dan menanggulangi dampak banjir. Penelitian dilakukan di wilayah pantai utara Jawa Barat Kabupaten Subang dan Kabupaten Karawang. Jenis data yang diambil adalah data primer dan data sekunder. Data primer diambil melalui teknik wawancara mendalam dan observasi dengan pelaku usaha budidaya ikan di tambak, sementara data sekunder diambil melalui wawancara dan kaji literatur terhadap dokumen Badan Penanggulangan Bencana Nasional dan data perikanan Dinas Kelautan dan Perikanan. Data dianalisis secara kualitatif dengan mengaitkan satu fenomena dengan fenomena lainnya berdasarkan analisis logik. Hasil analisis kemudian dijadikan bahan untuk merumuskan rekomendasi penanggulangan dampak banjir. Upaya pemerintah dalam melakukan mitigasi bencana banjir adalah dengan mengeluarkan UU No.24/ 2007, PP No. 21/2008, PP No.22/2008, PP No. 23/2008, dan Permen KP No.12/2014. Beberapa hal yang perlu diatur lebih lanjut adalah sumber pendanaan harus dialokasi secara khusus di dalam pos anggaran kementerian agar tidak mengganggu pos anggaran lainnya serta tata kelola tentang penanggulangan bencana alam di sektor kelautan dan perikanan seharusnya bersifat menyeluruh dan berjenjang dari mulai tingkat pusat hingga ke daerah yang melibatkan secara bersama seluruh elemen pemerintah dan masyarakat, terutama di tingkat daerah. Pada tataran masyarakat, jaringan sosial merupakan bentuk adaptasi pembudidaya ikan dalam menanggulangi dampak banjir. Jaringan sosial tersebut bisa menjamin sumber modal, sumber tenaga kerja, dan sumber iptek. Intervensi lebih lanjut dibutuhkan dalam penanggulangan tanggap darurat dan rehabilitasi sarana produksi, karena relasi yang sekarang terbentuk belum menyentuh kedua aspek ini.
\end{abstract}

Kata Kunci: mitigasi, adaptasi, banjir, budidaya ikan

\begin{abstract}
The study aimed to provide an overview of mitigation strategies undertaken by the government and also community adaptation strategies to cope with flooding disaster. The study was conducted in the northern coast of West Java Subang and Karawang District. Primary data were collected using in-depth interviewed and observation techniques with pond farmer actors, while secondary data were collected from literature review of National Disaster Management Agency and fisheries data of Marine and Fisheries documents. Data were analyzed qualitatively by linking causalitic phenomena based on logical analysis. The results would be used to formulate recommendations of flood impact mitigation strategy. Government had issued Government Act No.24 / 2007, Presidential Act No.21/2008, Presidential Act No. 22 / 2008, Presidential Act No.23/2008, and Ministrial Act of Marine and Fisheries No.12/2014 to mitigate flood disaster. Some details that should be further regulated were the funding source of mitigation budgetary should be allocated specifically in the ministrial budget so it would not disrupt other budget, and disaster management governance of marine and fisheries sectors should be comprehensive from local to national level that also included both government and community actors colaboratively
\end{abstract}


involved. At the community level, social network played significant role as an adaptation strategy to cope with flooding disaster. It could secure sources of capital, labor, and also science and technology. However, further intervention was needed for emergency response and also rehabilitation of production infrastructures, because of existing social network did not cope with those aspects.

Keywords: mitigation, adaptation, floods, fish culture

\section{PENDAHULUAN}

Kegiatan usaha budidaya ikan dan udang di tambak air payau merupakan kegiatan yang rentan terhadap bencana banjir baik yang berasal dari kenaikan permukaan air laut (rob) maupun karena tingginya curah hujan. Isu ini semakin mengemuka seiring dengan fenomena perubahan iklim yang semakin terasa dengan adanya perubahan pola iklim yang tidak dapat diprediksi oleh masyarakat khususnya pembudidaya ikan air payau di tambak.

Meskipun banjir merupakan sebuah fenomena yang terus berulang setiap tahunnya, namun ketidakmampuan masyarakat dalam memprediksi pola iklim mengakibatkan semakin buruknya kerusakan yang terjadi akibat banjir. Fenomena banjir 2014 misalnya, dirasakan oleh petambak sebagai bencana banjir terburuk selama 5 tahun terakhir. Selain ketidakmampuan memprediksi pola iklim, kerusakan akibat dampak banjir ini disebabkan kurangnya daya adaptasi petambak terhadap bencana banjir.

Selain faktor petambak, faktor kebijakan pemerintah pun turut berpengaruh terhadap penanggulangan bencana. Dalam hal penanganan banjir, pemerintah telah memberikan perhatian yang cukup besar, PERMEN-KP No 12/2014 tentang perlindungan nelayan, pembudidaya ikan dan petambak garam rakyat yang terkena bencana alam merupakan salah satu bentuk kepedulian pemerintah. Berdasarkan PERMEN-KP tersebut, kementerian melalui direktorat jendral terkait di bawahnya secara ad hoc dapat mengalokasi dana untuk memberikan bantuan kepada pelaku usaha yang terkena dampak bencana. Di masa mendatang, diharapkan dalam rangka upaya antisipasi dan respon secara cepat kejadian bencana alam berdampak pada keberlanjutan usaha sektor kelautan dan perikanan dapat dirwujudkan dalam bentuk prosedur operasional standar (SOP) yang dapat dijadikan acuan, baik dalam rangka valuasi dampak kerugian sebagai akibat bencana alam maupun tindak lanjut yang diperlukan secara cepat. Ketentuan peraturan perundangundangan di sektor kelautan dan perikanan terkait penanggulangan bencana yang ada belum dapat dijadikan landasan hukum yang kuat dan menyeluruh serta belum sesuai dengan perkembangan keadaan serta kebutuhan masyarakat sehigga menghambat upaya penanggulangan bencana secara terencana, terkoordinasi dan terpadu.

Hasil penelitian ini diharapkan dapat menjadi bahan masukan pemerintah dalam rangka membuat kebijakan terkait penanggulangan bencana banjir terhadap perikanan tambak di wilayah pesisir. Selain menggambarkan kebijakan dan aturan yang selama ini diterapkan dan pola adaptasi masyarakat dalam merespon bencana banjir, makalah ini mencoba menganalisis aspekaspek yang masih memerlukan perbaikan dalam kedua hal tersebut. Dengan demikian, diharapkan muncul sebuah kebijakan penanggulangan yang komprehensif, tepat waktu, dan tepat sasaran.

\section{METODOLOGI}

\section{Lokasi dan Waktu Penelitian}

Penelitian dilakukan di Pesisir Pantai Utara Jawa Barat Kabupaten Subang dan Kabupaten Karawang pada Bulan April sampai dengan Mei 2014. Dasar pertimbangan pemilihan lokasi adalah wilayah ini merupakan kawasan usaha budidaya ikan di tambak yang terkena dampak banjir setiap tahunnya.

\section{Data dan Sumber Data}

Penelitian merupakan penelitian kualitatif yaitu suatu proses penelitian untuk memahami masalah-masalah manusia atau sosial dengan menciptakan gambaran menyeluruh dan kompleks yang disajikan dengan kata-kata, melaporkan pandangan terinci yang diperoleh dari para sumber informasi serta dilakukan dalam latar (setting) yang alamiah (Creswell, 1994). Data yang dikumpulkan berupa data primer dan sekunder. Data primer yang dikumpulkan terkait dengan pola-pola relasi sosial dalam sistem produksi budidaya tambak, respons masyarakat atas kebijakan penanggulangan bencana, dan strategi adaptasi masyarakat dalam 
menghadapi bencana. Sementara data sekunder yang dikumpulkan terkait dengan tata aturan penanggulangan bencana dan potensi perikanan budidaya. Data primer dan sekunder dikumpulkan dari pelaku usaha budidaya ikan dan udang yang terkena dampak banjir, Koperasi petambak ikan, Dinas Kelautan dan Perikanan, dan Badan Penanggulangan Bencana Nasional. Jumlah informan dalam penelitian ini sebanyak 12 orang.

\section{Metode Pengumpulan Data}

Pengumpulan data primer dilakukan melalui wawancara mendalam dan studi dokumen terkait penanggulangan bencana banjir baik untuk skala lokal maupun nasional. Selain itu dilakukan pula observasi yaitu suatu kegiatan yang dimaksudkan untuk mendapatkan penjelasan yang lebih mendalam mengenai fenomena banjir yang tidak dapat diperoleh dari teknik wawancara.

\section{Analisis Data}

Data dianalisis secara deskriptif interpretatif yang merupakan suatu metode yang memusatkan pada pemecahan masalah yang ada pada masa sekarang atau masa aktual dengan jalan mengumpulkan, menyusun, mengklarifikasikan, menganalisis dan menginterpretasikan data yang ada (Surakhmad, 1989).

\section{POTENSI PERIKANAN BUDIDAYA}

Kabupaten Karawang dan Subang merupakan daerah yang berada di bagian utara Propinsi Jawa Barat yang memiliki potensi sumberdaya perikanan dan kelautan yang cukup besar. Pada Kabupaten Karawang, potensi sumberdaya perikanan dan kelautan yang dimiliki berasal dari perikanan tangkap maupun perikanan budidaya. Potensi yang dimilik pada perikanan tangkap sangat beraneka ragam serta memunyai nilai ekonomi yang cukup tinggi. Keadaan ini didukung oleh panjang pantai yang terbentang dibagian utara sepanjang $84,23 \mathrm{~km}$ serta hutan magrove seluas $9.983,93$ ha. Sedangkan untuk bidang perikanan budidaya potensi yang dimiliki berasal dari tambak, kolam, mina padi dan KJA. Potensi yang dimiliki untuk tambak sekitar $18.273,30$ ha (baru dimanfaatkan sekitar $15.567,40$ ha), potensi kolam budidaya seluas $1.279,40$ ha (baru dimanfaatkan 1.188,19 ha), potensi minapadi sekitar 10.580,80 ha (baru dimanfaatkan 141,05 ha) dan potensi KJA sebanyak 168 unit (baru dimanfaatkan 79 unit). Adapun jumlah rumah tangga perikanan (RTP) untuk pembudiaya ikan adalah 7.871 RTP yang terdiri dari 4.229 RTP tambak, 3.033 RTP kolam, 514 RTP mina padi dan 95 RTP KJA.

Jika dilihat dari potensi sumberdaya yang dimiliki, potensi dari perikanan budidaya khususnya tambak masih berpotensi untuk terus dikembangkan mengingat masih sekitar $15 \%$ lagi yang belum dimanfaatkan. Hal ini terlihat dari perkembangan jumlah produksi ikan selama 5 (lima) tahun terakhir (2009-2013) yang mengalami kenaikan rata-rata sebesar $20 \%$, dengan nilai produksi yang paling besar berasal dari budidaya tambak seperti terlihat pada Tabel 1.

Pada Kabupaten Subang, potensi sumberdaya perikanan dan kelautan yang dimiliki berasal dari perikanan tangkap maupun perikanan budidaya. Dari sektor perikanan budidaya, potensi yang dimiliki cukup besar yaitu dari potensi tambak seluas 10.000 ha (baru dimanfaatkan seluas 7.941 ha), kolam seluas 900 ha (baru dimanfaatkan 107,5 ha), kolam air deras sebanyak 1600 unit (baru dimanfaatkan sebanyak 665 unit), dan minapadi seluas 13.000 ha (pemanfaatan seluas 28 ha). Jika dilihat dari potensi yang dimiliki tersebut, peluang usaha untuk budidaya ikan air payau di Kabupaten

Tabel 1. Perkembangan Produksi Perikanan Budidaya Tahun 2009-2013 di Kabupaten Karawang. Table 1. The Status of Aquaculture Production at Karawang District, 2009-2013.

\begin{tabular}{lrrrrr}
\hline \multicolumn{1}{c}{ Perikanan Budidayal } & \multicolumn{5}{c}{ Produksi (Ton)/ Production (Ton) } \\
\cline { 2 - 6 } Aquaculture & \multicolumn{1}{c}{$\mathbf{2 0 0 9}$} & \multicolumn{1}{c}{$\mathbf{2 0 1 0}$} & \multicolumn{1}{c}{$\mathbf{2 0 1 1}$} & $\mathbf{2 0 1 2}$ & \multicolumn{1}{c}{$\mathbf{2 0 1 3}$} \\
\hline Tambak/ Shrimps Ponds & $35,005.49$ & $35,101.19$ & $35,267.54$ & $35,285.15$ & $36,648.48$ \\
Kolam/ Fishpond & $2,221.28$ & $2,225.35$ & $2,492.99$ & $2,517.00$ & $2,605.89$ \\
Mina Padi/ Paddy Fish Ponds & 671.47 & 611.92 & 409.8 & 364.17 & 360.87 \\
KJA/ Cages & 164.98 & 165.17 & 225.74 & 206.26 & 237.44 \\
\hline \multicolumn{1}{c}{ Jumlah/ Total } & $\mathbf{3 8 , 0 6 3 . 2 2}$ & $\mathbf{3 8 , 1 0 3 . 6 3}$ & $\mathbf{3 8 , 3 9 6 . 0 7}$ & $\mathbf{3 8 , 3 7 2 . 5 8}$ & $\mathbf{3 9 , 8 5 2 . 6 8}$ \\
\hline
\end{tabular}

Sumber: Dinas Perikanan dan Kelautan Kabupaten Karawang (2014)/ Source: Karawang Marine and Fisheries Agency (2014) 
Subang masih sangat besar, hal ini juga didukung oleh panjang pantai yang dimiliki yang mencapai $68 \mathrm{~km}$ yang potensial untuk pengembangan usaha budidaya laut. Komoditas yang sangat cocok untuk dikembangkan adalah Rumput Laut (Euchema spp), Kakap (Lates carcarifer), Kerapu (Ephinephelus spp), Udang Windu (Paneus monodon), Udang Putih (Paneus marguensis), Bandeng (Channos channos) dan Kerang-kerangan serta jenis ikan lainnya (Anonim, 2013).

Jika dilihat dari perkembangan produksi ikan selama 5 (lima) tahun terakhir (2009-2013) terjadi peningkatan rata-rata sebesar $20 \%$, dengan nilai produksi yang paling besar berasal dari budidaya tambak seperti terlihat pada Tabel 2. Untuk budidaya tambak, produksinya berasal dari udang windu, udang api-api, bandeng, dan jenis ikan lainnya.

\section{KEBIJAKAN DAN ATURAN LEGAL FORMAL PENANGGULANGAN BENCANA BANJIR}

Upaya yang dilakukan terkait penanganan dampak banjir terhadap sektor perikanan terbagi menjadi dua yaitu tanggap darurat dan rehabilitasi usaha. Tanggap darurat adalah serangkaian kegiatan yang dilakukan dengan segera pada saat kejadian bencana untuk menangani dampak buruk yang ditimbulkan, yang meliputi kegiatan penyelamatan dan evakuasi korban, harta benda, pemenuhan kebutuhan dasar, perlindungan, pengurusan pengungsi, penyelamatan, serta pemulihan prasarana dan sarana. Sedangkan rehabilitasi adalah perbaikan dan pemulihan sarana dan prasarana usaha masyarakat sampai tingkat yang memadai pada wilayah pasca bencana dengan sasaran utama normalisasi secara wajar usaha perikanan masyarakat di wilayah pasca bencana.

Hasil wawancara dengan Dinas Kelautan dan Perikanan Kabupaten Karawang dan Kabupaten Subang terkait dengan penanganan tanggap darurat diawali dengan pernyataan bupati tentang status bencana yang dinaikkan dari "status siaga" darurat menjadi "tanggap darurat bencana". Tanggap darurat bencana ditandai dengan:

a. Intensitas hujan tinggi,

b. Adanya rob air laut ke areal tambak tinggi

c. Infrastruktur pengairan, khususnya tanggul terjadi kerusakan (jebol)

d. Tambak-tambak terendam banjir

e. Petambak mengalami kerugian

Berdasarkan tanda tersebut, maka dinas KP menghitung jumlah rumah tangga petambak yang terkena banjir, serta memprediksi jumlah bantuan yang dibutuhkan. Usulan bantuan ditujukan kepada Bupati melalui Dinas Sosial. Setelah tanggap darurat terselesaikan, maka dinas dan instansi terkait akan menghitung jumlah kerugian dan kerusakan yang dialami oleh para petambak untuk menjadi dasar bagi bantuan rehabilitasi. Setelah terdapat hasil perhitungan, maka usulan bantuan rehabilitasi usaha tersebut akan ditujukan kepada Menteri Kelautan dan Perikanan.

Pemerintah sudah memberikan perhatian yang cukup besar terhadap penanganan dampak bencana terhadap keberlangsungan kehidupan masyarakat. Undang-Undang No 24/2007 tentang

Tabel 2. Perkembangan Produksi Perikanan Budidaya Tahun 2009-2013 di Kabupaten Subang.

Table 2. The Status of Aquaculture Production at Subang District, 2009-2013.

\begin{tabular}{lrrrrr}
\hline \multirow{2}{*}{$\begin{array}{c}\text { Perikanan Budidayal } \\
\text { Aquaculture }\end{array}$} & \multicolumn{5}{c}{ Produksi (Ton)/ Production (Ton) } \\
\cline { 2 - 6 } & $\mathbf{2 0 0 9}$ & $\mathbf{2 0 1 0}$ & $\mathbf{2 0 1 1}$ & $\mathbf{2 0 1 2}$ & \multicolumn{1}{c}{$\mathbf{2 0 1 3}$} \\
\hline Tambak/Shrimps ponds & $12,885.72$ & $13,610.00$ & $14,563.04$ & $18,754.64$ & $28,541.31$ \\
Kolam air tenang/ fish ponds & $6,256.97$ & $14,103.74$ & $14,187.98$ & $11,624.31$ & $9,276.00$ \\
Sawah/ Paddy fish Ponds & $1,168.87$ & 182.83 & 177.59 & 51.19 & 5.00 \\
Kolam air deras/ & $2,873.00$ & $4,708.19$ & $4,867.12$ & $5,138.26$ & $8,258.84$ \\
$\begin{array}{l}\text { Running fish ponds } \\
\text { Budidaya laut/ Marine culture }\end{array}$ & 440.00 & 85.00 & 88.00 & 72.00 & 36.00 \\
Karamba/Cages & & & & 4.58 & 7.00 \\
\hline \multicolumn{1}{c}{ Jumlah/Total } & $\mathbf{2 3 , 6 2 4 . 5 6}$ & $\mathbf{3 2 , 6 8 9 . 7 6}$ & $\mathbf{3 3 , 8 8 3 . 7 3}$ & $\mathbf{3 5 , 6 4 4 . 9 8}$ & $\mathbf{4 6 , 1 2 4 . 1 5}$ \\
\hline
\end{tabular}

Sumber: Dinas Kelautan dan Perikanan Kabupaten Subang (2014)/ Source: Subang Marine and Fisheries Agency (2014) 
penanggulangan bencana merumuskan pedoman umum mengenai mekanisme penanggulangan bencana yang harus dilakukan oleh pemerintah. Turunan dari Undang-Undang tersebut adalah Peraturan Pemerintah No 21 Tahun 2008 tentang penyelenggaraan Penanggulangan Bencana, Peraturan Pemerintah No 22 Tahun 2008 tentang Pendanaan dan Pengelolaan Bantuan Bencana serta Peraturan Pemerintah No. 23 Tahun 2008 tentang Peran Serta Lembaga Donor. Berdasarkan aturan tersebut, maka kementerian Kelautan dan Perikanan menyusun Permen KP No 12 tahun 2014 tentang Perlindungan Nelayan, Pembudidaya, dan Petambak Garam Yang Terkena Bencana Alam. Alur tata aturan terkait dengan penanggulangan bencana yang ada dapat dilihat pada Gambar 1 berikut.

Payung hukum di dalam upaya penanggulangan bencana alam pada sektor kelautan dan perikanan memang sudah tersedia. Namun demikian, terdapat beberapa hal yang masih belum diatur secara rinci di dalam peraturan turunan yang ada. Analisis isi yang dilakukan terhadap PERMEN KP No 12/2014 tentang Perlindungan Nelayan, Pembudidaya Ikan dan Petambak Garam Rakyat yang Terkena Bencana Alam dan dibandingkan dengan aturan sejenis pada stok lain (Stok Pertanian) dapat dilihat pada Tabel 3 berikut. Berdasarkan analisis isi yang dilakukan terhadap payung hukum yang ada, maka peluang penanggulangan bencana pada sektor Kelautan dan Perikanan dapat lebih ditingkatkan ke depannya dengan cara melengkapi dan merevisi aturan yang ada. Hal ini bertujuan agar penanggulangan bencana dapat dengan cepat dilakukan.

Hal penting yang seharusnya masuk di dalam peraturan pelaksanaan penanggulangan bencana di sektor kelautan dan perikanan adalah terkait dengan sumber pendanaan. Kementerian Kelautan dan Perikanan harus secara jelas dan tegas memasukkan sumber pendanaan ke dalam perencanaan penganggaran kementerian sebagai bagian yang tidak terpisahkan pada setiap tahunnya. Pengalokasian secara khusus di dalam pos anggaran kementerian dimungkinkan untuk dilakukan setiap tahunnya. Pengalokasian secara khusus ini dilakukan bertujuan agar tidak mengganggu pos anggaran lainnya yang sudah ada dan dapat dengan cepat dilakukan penyaluran bantuan untuk penanggulangan bencana.

Faktor tata kelola juga menjadi hal penting di dalam upaya melengkapi dan merevisi aturan yang saat ini sudah ada. Tata kelola menyangkut tentang organisasi dan pengorganisasian (mekanisme) yang meliputi kegiatan proses perencanaan, pelaksanaan serta monitoring dan evaluasi penanggulangan bencana. Dengan demikian, tata kelola tentang penanggulangan bencana alam di sektor kelautan dan perikanan seharusnya bersifat menyeluruh dan berjenjang dari mulai tingkat pusat hingga ke daerah yang melibatkan secara bersama seluruh elemen pemerintah dan masyarakat, terutama di tingkat daerah.

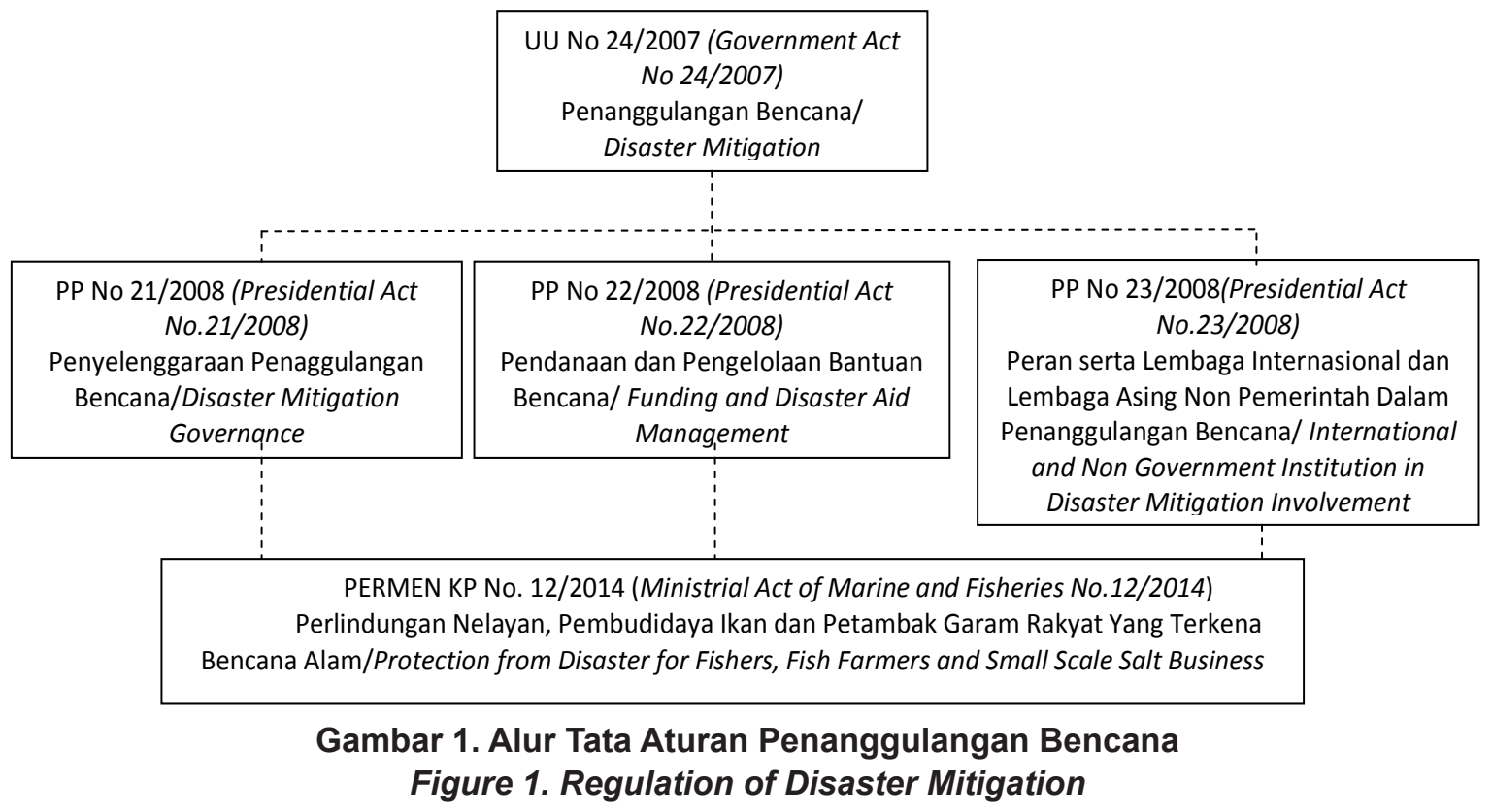


Tabel 3. Komparasi Aturan Penanggulangan Bencana Kementerian KP dan Kementerian Pertanian. Table 3. Comparison of Ministrial Act Level of Marine and Fisheries and Agricultural Sectors Regarding Disaster Mitigation.

\begin{tabular}{|c|c|c|}
\hline $\begin{array}{l}\text { Deskripsi/ } \\
\text { Description }\end{array}$ & $\begin{array}{l}\text { Kementerian KP'1/ } \\
\text { Minister of Marine } \\
\text { and Fisheries Affairs }\end{array}$ & $\begin{array}{c}\text { Kementerian Pertanian'2)/ } \\
\text { Minister of Agriculture }\end{array}$ \\
\hline $\begin{array}{l}\text { Bentuk bantuan/ } \\
\text { Aids }\end{array}$ & $\begin{array}{l}\text { Jenis dan bentuk telah diatur } \\
\text { (tanggap darurat dan pemulihan)/ } \\
\text { Type had been regulated } \\
\text { (emergency and rehabilitation) }\end{array}$ & $\begin{array}{l}\text { Jenis dan bentuk telah diatur (tanggap } \\
\text { darurat dan pemulihan)/ Type had been } \\
\text { regulated (emergency and rehabilitation) }\end{array}$ \\
\hline $\begin{array}{l}\text { Sumber } \\
\text { pendanaan/ } \\
\text { Source of funding }\end{array}$ & $\begin{array}{l}\text { Belum mengatur dan } \\
\text { mengalokasikan secara khusus } \\
\text { sumber pendanaan secara jelas } \\
\text { di dalam anggaran stok/ Source } \\
\text { of budgetary had not been } \\
\text { specifically regulated }\end{array}$ & $\begin{array}{l}\text { Sudah mengatur dan mengalokasikan } \\
\text { secara khusus sumber pendanaan } \\
\text { secara jelas di dalam anggaran stok } \\
\text { setiap tahunnya/ Source of budgetary } \\
\text { had been specifically regulated }\end{array}$ \\
\hline $\begin{array}{l}\text { Tata kelola } \\
\text { penyaluran } \\
\text { bantuan/ Aid } \\
\text { management }\end{array}$ & $\begin{array}{l}\text { - Untuk tanggap darurat harus } \\
\text { berkoordinasi dengan stok sosial/ } \\
\text { For emergency status should } \\
\text { coordinated with Minister of } \\
\text { Social } \\
\text { - Membentuk tim satuan tugas } \\
\text { pada tingkat pusat/ Developing } \\
\text { national task force } \\
\text { - Belum menentukan mekanisme } \\
\text { penentuan sasaran/ Had not } \\
\text { developed aid target system } \\
\text { - Belum efektif di dalam teknis/ } \\
\text { Technically inefficient }\end{array}$ & $\begin{array}{l}\text { - Dapat menyalurkan bantuan } \\
\text { baik berupa tanggap darurat dan } \\
\text { rehabilitasi dengan cepat karena } \\
\text { tersedianya pos anggaran/ Both } \\
\text { emergency and rehabilitation status } \\
\text { could be delivered fast because of } \\
\text { budget availability } \\
\text { - Pembentukan tim satuan tugas dari } \\
\text { tingkat pusat hingga ke tingkat daerah/ } \\
\text { Developing national and also local } \\
\text { task force } \\
\text { - Telah memiliki mekanisme penentuan } \\
\text { sasaran (PCL)/ Had developed aid } \\
\text { target system } \\
\text { - Telah memiliki mekanisme penyaluran } \\
\text { bantuan secara rinci/ Had detail aid } \\
\text { management }\end{array}$ \\
\hline
\end{tabular}

Keterangan/ Notes : 1) PERMEN KP No 12/2014 tentang Perlindungan Nelayan, Pembudidaya Ikan dan Petambak Garam Rakyat yang Terkena Bencana Alam/ Ministrial Act of Marine and Fisheries No.12/2014 of Disaster Protection from Disaster for Fishers, Fish Farmers and Small Scale Salt Business

2) PERMEN PERTANIAN No 50/2007 tentang Pedoman Penanggulangan Dampak Bencana di Bidang Pertanian/ Ministrial Act of Agriculture No 50/2007 of Disaster Management at Agriculture Sectors

\section{STRATEGI ADAPTASI MASYARAKAT TERHADAP BENCANA BANJIR}

Petambak ikan dan udang di dalam operasional usahanya memanfaatkan pola-pola relasi produksi yang ada. Pola relasi produksi ini tidak hanya terbatas pada kaitan jaringan kerja antara pemilik dengan buruh, namun juga meluas hingga jaringan input barang produksi dan pemasaran. Pola relasi ini terbentuk karena adanya basis kepentingan yang beragam diantara setiap aktor atau pelaku usaha yang ada. Pola relasi ini tidak hanya berfungsi secara ekonomi semata, namun juga memiliki fungsi jaminan sosial di masyarakat. Fungsi jaminan sosial ini terjadi disebabkan karena sebenarnya bentuk relasi yang terjadi lebih mengarah kepada bentuk patron-klien, bukan sebagai bentuk kemitraan usaha murni diantara para pelaku usaha.

Jaminan sosial merupakan suatu bentuk pola adaptasi dari masyarakat ketika dihadapkan pada permasalahan akan adanya keterbatasan akses terhadap sumberdaya (Priyatna, 2005). Sumber daya dalam hal ini tidak hanya dipahami sebagai sumber daya alam semata, namun juga sejatinya dapat dipandang sebagai sebuah bentuk modal (kapital) yang bekerja secara dinamis dengan bentuk kapital lainya seperti: finansial, fisik (teknologi dan tenaga kerja), sosial dan kultural. Abdullah (2001) dalam Benda-Beckmann (2001), menyebutkan bahwa masyarakat akan menciptakan 
jaringan pengaman sosial yang dapat menjamin keberlangsungan terhadap mereka, seperti halnya kebutuhan akan modal ketika saluran-saluran formal yang ada tidak mampu untuk memberikan jaminan kepada masyarakat.

Petambak umumnya mempunyai jaringan yang memadai baik untuk meningkatkan kemampuan produksi usaha tambaknya maupun sebagai jaminan keberlangsungan produksi disaat mereka sedang menderita kerugian seperti pada saat banjir. Bagi petambak yang mempunyai jaringan, yang memadai usaha tersebut dapat segera pulih setelah terjadinya bencana. Pembudidaya tambak di lokasi penelitian setidaknya memiliki relasi terhadap keempat bentuk penyedia kapital. Relasi petambak dengan penyedia kapital finansial terjadi dengan aktor atau pelaku seperti tengkulak, atau pun koperasi. Sementara terkait dengan penyedia kapital fisik, dilakukan baik secara langsung maupun tidak langsung dengan tenaga kerja (buruh harian, buruh panen dan lainnya), penyedia benih serta pedagang input produksi lainnya (pakan, pupuk dan obat-obatan, BBM dan lainnya). Relasi yang terjadi antara petambak dengan penyedia kapital sosial berikut kapital kultural terjadi melalui kelompokkelompok sosial yang ada di masyarakat, seperti halnya kelompok profesi, maupun kelembagaankelembagaan kemasyarakatan serta pemerintahan.

Pola relasi tersebut tidak bersifat "suka rela", namun memiliki basis kepentingan yang berbeda dan saling melengkapi serta saling membutuhkan. Secara umum basis kepentingan yang ada adalah kepentingan ekonomi, yaitu menjamin keberlangsungan usaha diantara setiap aktor atau pelaku yang terlibat. Namun demikian, derajat kebutuhan dan kepentingan yang ada berbeda satu dengan lainnya. Mengingat pembudidaya tambak yang ada lebih mengarah kepada tingkat skala usaha kecil, maka sumber permasalahan utama adalah pada permasalahan permodalan usaha dan penyedia sarana input produksi. Sumber permasalahan ini membentuk basis kepentingan ekonomi diantara petambak dengan tengkulak atau sumber permodalan finansial lainnya.

Petambak memiliki sumber permodalan dari berbagai pihak yaitu KUD, Bakul Benih, dan Pemilik, dan tengkulak. Setiap garis hubungan yang dijalin oleh petambak dan sumber modal memiliki karakteristik tersendiri. Relasi antara petambak dengan Koperasi Unit Desa (KUD) merupakan relasi yang berdasarkan saling ketergantungan. Petambak mempunyai kepentingan dalam hal pengadaan modal. Namun untuk mendapatkan fasilitas tersebut petambak harus menjadi anggota koperasi dan menjual semua hasil produksinya ke koperasi. Penjualan hasil ke koperasi bagi sebagian responden penelitian tidak menjadi masalah karena dengan demikian mereka mempunyai jaminan pasar yang jelas dan terbuka karena melalui proses lelang.

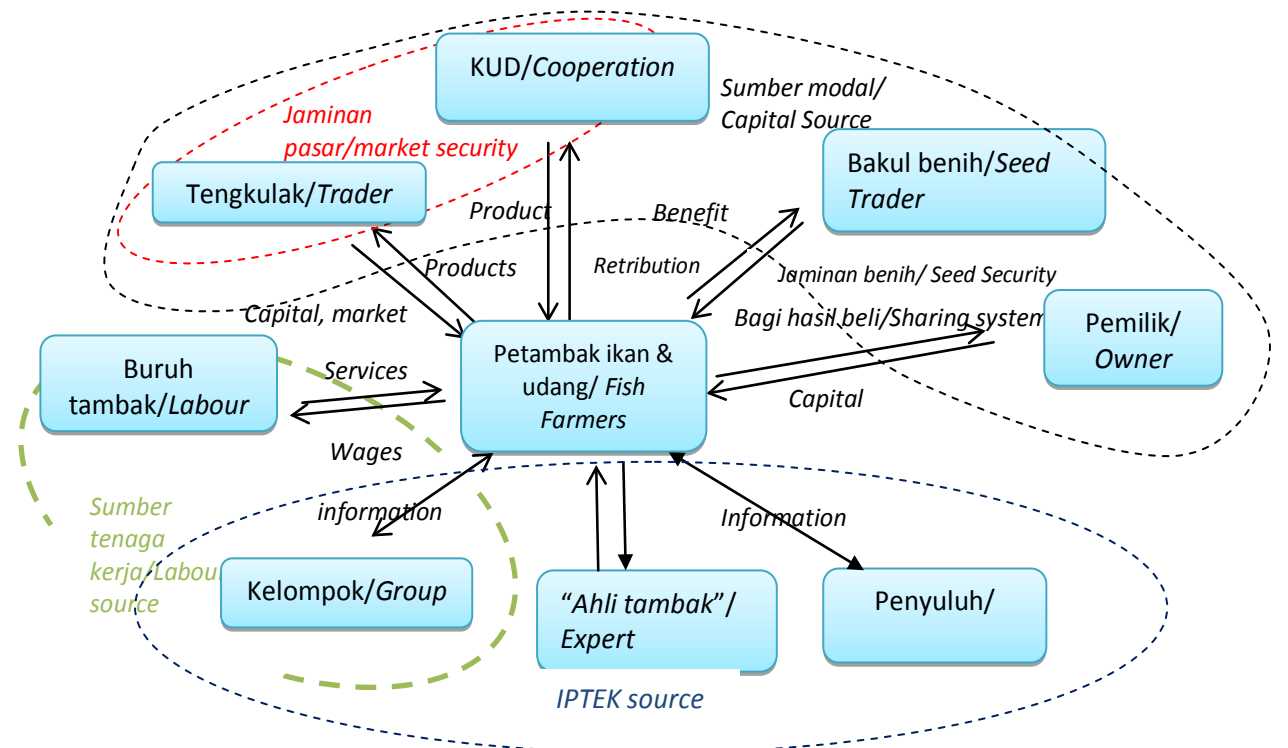

Gambar 2. Jaringan Usaha dan Pola Hubungan Antar Pelaku Usaha Tambak IkanTradisional di Kabupaten Subang dan Karawang.

Figure 2. Business Network and Traditional Pond Farmer's Relationship Pattern at Subang and Karawang District. 
Penyedia modal, sangat berperan dalam mendorong petambak untuk bangkit setelah terjadi bencana banjir. Koperasi selain memberikan pinjaman modal juga memberikan bantuan yang berasal dari keuntungan koperasi dan memfasilitasi penyediaan data kerugian sebagai bahan laporan untuk pihak yang membutuhkan serta bahan untuk bahan meminta bantuan kepada instansi terkait. Bakul benih pun berperan dalam penyediaan modal khususnya benih. Sistem pembayaran bisa dilakukan dengan dua cara yaitu kontan dan tunda panen. Bagi petambak yang merugi akibat banjir biasanya akan melakukan pembayaran dengan cara tunda panen, yaitu membayar ketika panen berlangsung. Meskipun harganya lebih tinggi dibandingkan dengan pembayaran kontan, namun cara ini merupakan cara yang paling memungkinkan setelah modal habis terkena bencana banjir.

Ketergantungan petambak terutama terhadap tengkulak/ pedagang pengumpul serta bakul benih sangatlah tinggi. Hal ini terjadi karena jaringan sosial yang terbentuk sebenarnya juga berupa sumber jaminan sosial bagi petambak. Namun demikian, beberapa kendala terjadi di saat situasi dan kondisi ekstrem menimpa kegiatan usaha budidaya dalam skala luas, seperti halnya saat terjadinya bencana. Kendala ini dapat teridentifikasi pada dua level atau tingkatan aktor, yaitu pembudidaya dan sumber permodalan. Kendala pada tingkatan aktor pembudidaya adalah keterbatasan pada sumber permodalan, baik pada pemenuhan kebutuhan untuk perbaikan sarana produksi maupun penyediaan sarana input produksi. Pada pembudidaya skala kecil permasalahan utama lebih besar akibat tidak tersedianya permodalan. Sementara pada pembudidaya skala menengah permasalahan utama lebih kepada ketersediaan barang input produksi. Kendala pada tingkatan aktor sumber permodalan adalah terbatasnya kapasitas kapital untuk "menjamin" klien (aktor pembudidaya) yang dimiliki dalam penyediaan permodalan usaha maupun benih.

Secara umum, meskipun pola relasi antara aktor pembudidaya dan sumber permodalan tetap berjalan namun keterbatasan kemampuan penyedia sumber permodalan tradisional untuk mengantisipasi kejadian luar biasa seperti bencana banjir menghambat proses pemulihan usaha budidaya secara mandiri. Faktor utama terhambat dan lambatnya proses pemulihan usaha budidaya secara mandiri lebih disebabkan karena faktor kurang tersedianya benih akibat tidak berimbangnya antara ketersediaan benih dengan tingginya tingkat permintaan benih. Bakul benih di dalam hal ini hanya berperan sebagai supplier atau pedagang pemasok benih, bukan sebagai pelaku pembenihan. Akibatnya pasokan benih sangat bergantung terhadap ketersediaan stok benih di sentra-sentra usaha pembenihan. Tingginya permintaan menyebabkan meningkatnya harga jual benih yang ditambah lagi dengan faktor rusaknya sarana prasarana jalan penghubung antar wilayah yang semakin meningkatkan harga benih.

\section{PENUTUP}

Upaya pemerintah dalam melakukan mitigasi bencana banjir diwujudkan dengan mengeluarkan UU No. 24/ 2007, PP No. 21/2008, PP No. 22/2008, PP No. 23/2008, dan Permen KP No. 12/2014. Beberapa hal yang perlu diatur lebih lanjut adalah sumber pendanaan harus dialokasi secara khusus di dalam pos anggaran kementerian agar tidak mengganggu pos anggaran lainnya serta tata kelola tentang penanggulangan bencana alam di sektor kelautan dan perikanan seharusnya bersifat menyeluruh dan berjenjang dari mulai tingkat pusat hingga ke daerah yang melibatkan secara bersama seluruh elemen pemerintah dan masyarakat, terutama di tingkat daerah. Pada tataran masyarakat, jaringan sosial merupakan bentuk adaptasi pembudidaya ikan dalam menanggulangi dampak banjir. Jaringan sosial tersebut berkontribusi dalam hal penanggulangan sumber modal, sumber tenaga kerja, dan sumber iptek. Intervensi lebih lanjut dibutuhkan dalam penanggulangan tanggap darurat dan rehabilitasi sarana produksi, karena relasi yang sekarang terbentuk belum menyentuh aspek ini.

\section{DAFTAR PUSTAKA}

Anonim. 2013. Blanakan Semakin Berkermbang dengan Program Revitalisasi http://www. djpb.kkp.go.id/berita. php?id=880. (Diakses pada 25 Oktober 2013).

Benda-Beckmann. 2001. Sumberdaya dan Jaminan Sosial. Pustaka Pelajar. Yogyakarta

Creswell, J. W. 1994. Research Design: Qualitative and Quantitative Approaches.Sage Publications

Dinas Perikanan dan Kelautan Kabupaten Karawang. 2014. Laporan Tahunan. Kabupaten Karawang. 
Dinas Perikanan dan Kelautan Kabupaten Subang. 2014. Laporan Tahunan. Kabupaten Subang.

Priyatna, F. N. 2004. Sumberdaya dan Jaminan Sosial di Masyarakat Nelayan Desa Karangjaladri, Kecamatan Parigi, Kabupaten Ciamis. Prosiding Seminar. Indikator Kinerja dan Hasil Riset Sosial Ekonomi Kelautan dan Perikanan. Balai Besar Riset Sosial Ekonomi Kelautan dan Perikanan. Jakarta.

Kementerian Kelautan dan Perikanan. 2014. Peraturan Menteri Kelautan dan Perikanan No 12 Tahun 2014 tentang Perlindungan Nelayan, Pembudidaya Ikan dan Petambak Garam Rakyat yang Terkena Bencana Alam. KKP-RI. Jakarta

Kementerian Pertanian. 2007. Peraturan Menteri Pertanian Nomor 50/Permentan/ OT.140/6/2007 Tentang Pedoman Penanggulangan Dampak Bencana di Bidang Pertanian. Kementan-RI. Jakarta.
Pemerintah Republik Indonesia. 2008. Peraturan Pemerintah Republik Indonesia Nomor 21 Tahun 2008 Tentang Penyelenggaraan Penanggulangan Bencana. Pemerintah RI. Jakarta.

Pemerintah Republik Indonesia. 2008. Peraturan Pemerintah Republik Indonesia Nomor 22 Tahun 2008 Tentang Pendanaan Dan Pengelolaan Bantuan Bencana. Pemerintah RI. Jakarta.

Pemerintah Republik Indonesia. 2008. Peraturan Pemerintah Republik Indonesia Nomor 23 Tahun 2008 Tentang Peran Serta Lembaga Internasional dan Lembaga Asing Nonpemerintah Dalam Penanggulangan Bencana. Pemerintah RI. Jakarta.

Pemerintah Republik Indonesia. 2007. Undang-Undang Nomor 24 Tahun 2007 Tentang Penanggulangan Bencana. Pemerintah RI. Jakarta.

Surakhmad, W. 1989. Pengantar Penelitian IImiah: Dasar, Metode dan Teknik. Tarsito. Bandung. 